\title{
Hiponatremia pada Anak Pasca Tindakan Operasi : Etiologi dan Faktor- faktor yang Berhubungan
}

\author{
Angelina, Antonius H. Pudjiadi, Setyo Handryastuti, Idham Amir, Evita B. Ifran, Mulya R. Karyanti \\ Departemen Ilmu Kesehatan Anak Fakultas Kedokteran Universitas Indonesia Rumah Sakit Cipto Mangunkusumo, Jakarta
}

\begin{abstract}
Latar belakang. Kejadian hiponatremia pada anak pasca-operasi berkisar antara 20-40\%. Hiponatremia yang tidak terdeteksi dapat meningkatkan mortalitas dan menyebabkan luaran neurologis yang buruk. Beberapa mekanisme yang berperan adalah sindrom hormon antidiuretik tidak tepat (SHATT) dan sick cell syndrome (SCS).

Tujuan. Mengetahui insidens hiponatremia pada anak pasca-operasi, kemungkinan penyebab yang melatarbelakangi, serta faktor yang berhubungan.

Metode. Penelitian potong lintang analitik dilakukan di ruang perawatan intensif terhadap anak berusia 1 bulan sampai 18 tahun yang menjalani tindakan operasi mayor dan masuk ruang perawatan intensif pediatrik RSCM selama bulan Mei sampai Desember 2016. Hasil. Terdapat 65 subyek menjalani operasi mayor, 87,69\% dilakukan secara elektif, jenis operasi terbanyak adalah hepatogastrointestinal (38,46\%) dan muskuloskeletal (20,00\%). Kadar natrium plasma pasca-operasi turun, kejadian hiponatremia 43,07\% dan $26,16 \%$ pada 12 dan 24 jam pasca-operasi. Nilai osmolalitas plasma yang normal atau meningkat dan osmolalitas urin $>100$ $\mathrm{mOsm} / \mathrm{kg}$. Sebanyak $70 \%$ subyek hiponatremia memiliki natrium urin $>30 \mathrm{mEq} / \mathrm{L}$. Faktor yang berhubungan dengan hiponatremia 12 jam pasca-operasi adalah status kegawatdaruratan operasi $(\mathrm{p}=0,007)$ dan perdarahan intraoperatif $(\mathrm{p}=0,024)$, sedangkan pada 24 jam pasca-operasi hanya status kegawatdaruratan operasi $(\mathrm{p}=0,001)$.

Kesimpulan. Terdapat 43,07\% dan 26,16\% subyek yang mengalami hiponatremia pada 12 dan 24 jam pasca-operasi mayor. Sindrom hormon antidiuretik tidak tepat tidak terbukti menjadi penyebab utama terjadinya hiponatremia, dan hiponatremia translokasional pada SCS mungkin berperan. Hiponatremia pasca-operasi berhubungan dengan status kegawatdaruratan operasi dan jumlah perdarahan intraoperatif. Sari Pediatri 2017;19(2):63-70
\end{abstract}

Kata kunci: hiponatremia, pasca-operasi, hormon antidiuretik, sick cell sydrome

\section{Hyponatremia in Post-surgery Pediatric Patients: Etiology and Its Related Factors}

Angelina, Antonius H. Pudjiadi, Setyo Handryastuti, Idham Amir, Evita B. Ifran, Mulya R. Karyanti

Background. The incidence of hyponatremia in post-surgery pediatric patients is $20-40 \%$. Undetected hyponatremia correlates with higher mortality and poor neurology outcomes. There are several mechanisms in post-surgery hyponatremia, such as syndrome of inappropriate antidiuretic hormone and sick cell syndrome.

Objective. To establish the incidence of hyponatremia among post-surgery pediatric patients, possible etiologies, and its related factors. Method. Observational analytic study was conducted forchildren aged 1 month until 18 years old after underwent major surgery in CM hospital pediatric intensive care unit, between May and December 2016.

Results. There were 65 subjects underwent mayor surgery, mostly (87.69\%) were elective surgery. The most common surgeries were hepato-gastrointestinal $(38,46 \%)$ and musculoskeletal $(20,00 \%)$ surgery. There was significant reductionof plasma natrium after surgery, with hyponatremia incidence at 12 and 24 hours post-surgery were $43.07 \%$ and $26.16 \%$. All subjects with hyponatremia had normal or increased plasma osmolality and urine osmolality $>100 \mathrm{mOsm} / \mathrm{kg}$. More than $70 \%$ subjects with hyponatremia had sodium urine $>30 \mathrm{mEq} / \mathrm{L}$. Hyponatremia 12 hours post-surgery was related to surgery emergency status $(\mathrm{p}=0.007)$ and intraoperative bleeding ( $\mathrm{p}=0.024)$, while hyponatremia observed 24 hours post-surgery was related only to surgery emergency status ( $\mathrm{p}=0.001)$. Conclusion. There was $43.07 \%$ and $26.16 \%$ subjects with hyponatremia at 12 and 24 hours post-surgery. Syndrome of inappropriate antidiuretic hormone was not proven to cause hyponatremia, and translocational hyponatremia in sick cell syndrome might be involved. Hyponatremia in post-surgery was related to surgery emergency status and intraoperative bleeding. Sari Pediatri 2017;19(2):63-70

Keywords: hyponatremia, post-surgery, antidiuretic hormone, sick cell syndrome

Alamat korespondensi: Dr. Angelina. Departemen Ilmu Kesehatan Anak Fakultas Kedokteran Universitas Indonesia Rumah Sakit Cipto Mangunkusumo, Jakarta. E-mail: angelina.now@gmail.com 
$\mathrm{H}$ iponatremia terjadi pada 10\%-30\% anak yang menjalani rawat inap di rumah sakit. ${ }^{1-4}$ Morbiditas dan mortalitas akibat hiponatremia banyak dilaporkan, terutama berkaitan dengan kejadian ensefalopati hiponatremia. ${ }^{5-7}$ Pasien anak yang menjalani tindakan operasi rentan mengalami hiponatremia pascaoperasi, yaitu antara $20 \%-40 \% .^{6,8,9}$ Ensefalopati hiponatremia pasca-operasi seringkali sulit dideteksi karena manifestasi awalnya tidak spesifik sehingga lebih banyak dikaitkan dengan penyakit dasar serta efek obat sedasi dan anestesi yang diberikan. Kegagalan mengenali terjadinya ensefalopati hiponatremia dan keterlambatan tata laksana menyebabkan luaran neurologis yang buruk. ${ }^{2,5}$

Hiponatremia pasca-operasi banyak dikaitkan dengan peningkatan sekresi hormon antidiuretik (HAD) akibat stimulus non osmotik dan pemberian cairan pasca operasi yang tidak tepat. ${ }^{1,5,8,10}$ Kadar HAD pasca-operasi akan meningkat sebagai respon stres hormonal yang fisiologis, tetapi pada beberapa orang sekresi HAD dapat terjadi secara berlebihan sehingga menyebabkan SHATT.5,11,12 Stimulus non osmotik, seperti nyeri, mual, muntah, hipoksia, asidosis, dan penggunaan beberapa jenis obat anestesia dapat secara poten merangsang sekresi HAD. ${ }^{5,13,14}$

Terapi cairan yang tepat pada pasien pascaoperasi sampai sekarang masih menjadi kontroversi. Penggunaan cairan hipotonik sebagai cairan rumatan masih merupakan terapi standar, padahal penelitian menunjukkan bahwa hiponatremia pasca-operasi berhubungan erat dengan penggunaan cairan hipotonik. ${ }^{1,2,6}$ Pada suatu survei yang dilakukan terhadap ahli anestesi di Inggris pada tahun 2006, $87 \%$ mengatakan akan meresepkan cairan hipotonik untuk rumatan anak pasca-operasi. ${ }^{15}$ Penelitian di Rumah Sakit Cipto Mangunkusumo (RSCM), Jakarta, menunjukkan bahwa cairan hipotonik dektrosa $10 \%$ dalam I/s salin normal (D10 1/5NS) merupakan cairan utama yang rutin. ${ }^{9,16}$

Terdapat beberapa mekanisme lain yang juga berperan dalam menyebabkan hiponatremia pascaoperasi. Hiponatremia akibat hipovolemia tidak jarang ditemukan pada pasien pasca-operasi yang belum stabil. ${ }^{13}$ Mekanisme lainnya adalah cerebral salt wasting (CSW), hiponatremia translokasional, dan sick cell syndrome. ${ }^{8,17,18}$ Risiko terjadinya hiponatremia pasca-operasi serta potensi bahaya yang ditimbulkan belum banyak disadari oleh para dokter yang bekerja di ruang perawatan intensif sehingga peneliti merasa bahwa penelitian mengenai hiponatremia pada pasien anak pasca-operasi perlu dilakukan.

\section{Metode}

Penelitian potong lintang analitik dilakukan di ruang perawatan intensif anak RSCM pada bulan Mei 2016 sampai dengan Desember 2016. Subyek penelitian adalah anak berusia 1 bulan sampai 18 tahun yang menjalankan tindakan operasi mayor dalam anestesi umum, dan masuk ruang perawatan intensif pediatrik RSCM. Subyek yang diketahui mengalami hipotiroid, defisiensi glukokortikoid, kelainan ginjal, gagal hati, gagal jantung, menggunakan obat-obat diuretik, mengalami hiponatremia atau hipernatremia sebelum tindakan operasi, atau mengalami hipovolemia pada saat akan dilakukan pengambilan sampel tidak diikutsertakan dalam penelitian.

Pemantauan status hidrasi dan klinis hiponatremia dilakukan bersama dengan dokter yang bertugas di ruang perawatan intensif. Pengambilan sampel darah, berupa elektrolit darah, elektrolit urin, osmolalitas darah, dan osmolalitas urin dilakukan dua kali, yaitu 12 dan 24 jam pasca-operasi. Analisis bivariat dilakukan untuk mengetahui hubungan antara kejadian hiponatremia pasca-operasi dengan jenis dan durasi operasi, status kegawatdaruratan operasi, kehilangan darah intraoperatif, jumlah cairan yang diberikan intraoperatif, diuresis intraoperatif, penggunaan ventilator mekanik pasca-operasi, serta jenis dan jumlah cairan yang diberikan setelah operasi. Program statistik yang digunakan untuk mengolah data adalah SPSS versi 21.0.

\section{Hasil}

Didapatkan 65 subyek penelitian yang sesuai dengan kriteria inklusi dan eksklusi, rerata usia $8,18 \pm 6,18$ tahun. Tindakan operasi bersifat elektif $(87,69 \%)$ dan jenis operasi terbanyak berkaitan dengan hepar dan saluran cerna $(38,46 \%)$ serta muskuloskeletal $(20,00 \%)$. Tindakan operasi lain meliputi operasi dalam bidang THT-KL (10,77\%), kardiotoraks (10,77\%), $\operatorname{SSP}(9,23 \%)$, dan lain-lain. Cairan isotonik diberikan 
selama operasi, 11 subyek mendapat tambahan cairan hipotonik berupa dektosa 1\% (Tabel 1).

Pada 12 dan 24 jam pasca tindakan operasi terdapat $20(30,77 \%)$ dan $11(16,92 \%)$ subyek yang masih menggunakan ventilator mekanik. Sebanyak 58 subyek masih mendapat cairan parenteral setelah 24 jam pasca tindakan operasi. Cairan rumatan parenteral yang diberikan adalah cairan hipotonik berupa campuran dekstrosa dan salin normal, dengan dekstosa $10 \%$ dalam $1 / 5$ salin normal merupakan cairan terbanyak yang digunakan $(92,30 \%$ subyek pada 12 jam pascaoperasi dan $68,97 \%$ subyek pada 24 jam pasca-operasi). Total balans cairan pada $24 \mathrm{jam}$ pasca-operasi $(+0,27 \pm 1,25 \mathrm{ml} / \mathrm{kg} / \mathrm{jam})$ lebih kecil dibandingkan dengan total balans cairan pada 12 jam pasca-operasi $(+0,61 \pm 1,21 \mathrm{ml} / \mathrm{kg} / \mathrm{jam})$, dan diuresis pada $24 \mathrm{jam}$ pasca-operasi $(1,88 \pm 0,96 \mathrm{ml} / \mathrm{kg} / \mathrm{jam})$ lebih banyak dibandingkan dengan diuresis pada 12 jam pascaoperasi $(1,67 \pm 1,02 \mathrm{ml} / \mathrm{kg} / \mathrm{jam})$. Perbedaan keduanya memiliki nilai $\mathrm{p}<0,001$. Pada 12 dan 24 jam pascaoperasi juga didapatkan penurunan kadar natrium plasma dibandingkan dengan kondisi pre-operatif (Gambar 1).
Kejadian hiponatremia pada 12 jam dan 24 jam pasca-operasi adalah 43,07\% dan 26,16\% (Tabel $3)$. Tidak ada subyek dengan hiponatremia yang mengalami manifestasi gangguan neurologis yang jelas. Enam orang subyek tidak dilakukan pemeriksaan pada

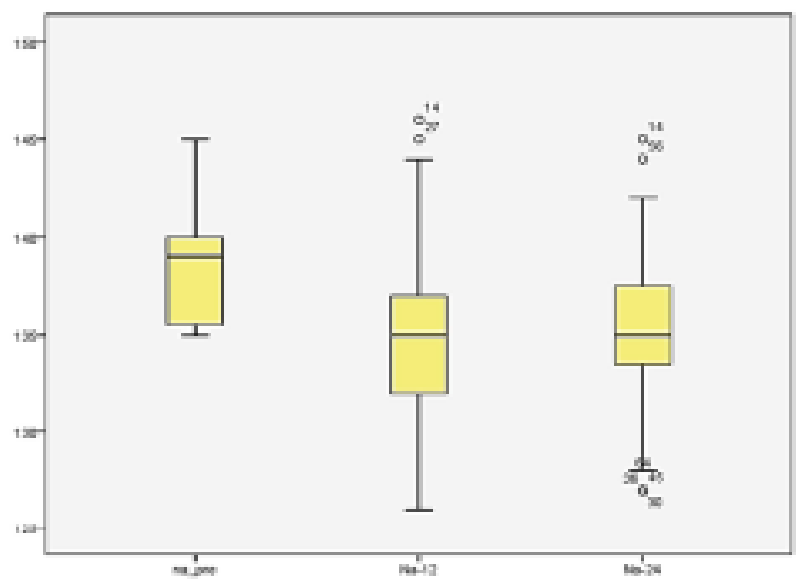

*perbedaan antara $\mathrm{Na}$ awal dengan $\mathrm{Na} 12$ jam, $\mathrm{Na}$ awal dengan $\mathrm{Na} 24$, serta $\mathrm{Na} 12$ dan 24 jam memiliki $\mathrm{p}<0,005$

Gambar 1. Perbandingan kadar natrium plasma pada saat sebelum operasi ( $\mathrm{Na}$ awal), 12 jam, dan 24 jam pasca-operasi

Tabel 1. Profil intraoperasi

\begin{tabular}{llc}
\hline Variabel & & $\begin{array}{c}\text { Jumlah atau nilai rerata/median (SD atau } \\
\text { min s/d maks) }\end{array}$ \\
\hline Cairan kristaloid (\%) & Ringer asetat & $37(56,92)$ \\
& Ringerfundin & $27(41,54)$ \\
& Ringer laktat & $1(1,54)$ \\
Cairan koloid (\%) & Gelofusin & $19(39,58)$ \\
& Albumin 5\% & $9(18,75)$ \\
Durasi operasi (jam) & & $4(1 \mathrm{~s} / \mathrm{d} 16)$ \\
Balans cairan $(\mathrm{ml} / \mathrm{kg} / \mathrm{jam})$ & & $5,48(-3,83 \mathrm{~s} / \mathrm{d}+297)$ \\
Diuresis $(\mathrm{ml} / \mathrm{kg} /$ jam) & & $2,48(0 \mathrm{~s} / \mathrm{d} 12,90)$ \\
Perdarahan intraoperasi $(\mathrm{ml} / \mathrm{kg})$ & & $24,45 \pm 31,09$ \\
\hline
\end{tabular}

Tabel 2. Kejadian hiponatremia pada 12 jam dan 24 jam pasca-operasi

\begin{tabular}{lccc}
\hline & $\begin{array}{c}12 \text { jam pasca-operasi } \\
\mathrm{n}(\%)\end{array}$ & $\begin{array}{c}24 \text { jam pasca-operasi } \\
\mathrm{n}(\%)\end{array}$ & Nilai $\mathrm{p}$ \\
\hline Hiponatremia ringan & $23(35,38)$ & $8(12,31)$ & \\
Hiponatremia sedang & $4(6,15)$ & $9(13,85)$ & \\
Hiponatremia berat & $1(1,54 \%)$ & $0(0)$ & \\
Total & $28(43,07)$ & $17(26,16)$ & 0,021 \\
\hline
\end{tabular}


Angelina dkk: Hiponatremia pasca tindakan operasi : etiologi dan faktor-faktor yang berhubungan

Tabel 3. Kadar osmolalitas plasma, osmolalitas urin, dan elektrolit urin

\begin{tabular}{lccc}
\hline & 12 jam pasca-operasi & 24 jam pasca-operasi & $p$ \\
\hline Osmolalitas plasma $(\mathrm{mOsm} / \mathrm{kg})$ & $302(285 \mathrm{~s} / \mathrm{d} \mathrm{446)}$ & $299,88 \pm 12,01$ & 0,559 \\
Osmolalitas urin $(\mathrm{mOsm} / \mathrm{kg})$ & $585,46 \pm 280,39$ & $472,18 \pm 240,71$ & 0,003 \\
Natrium urin $(\mathrm{mEq} / \mathrm{L})$ & $67,5(4 \mathrm{~s} / \mathrm{d} \mathrm{333})$ & $75,35 \pm 58,32$ & 0,160 \\
\hline
\end{tabular}

Tabel 4. Hubungan antara durasi operasi, perdarahan intraoperatif, balans diuresis intraoperatif, dan balans diuresis pasca-operasi

\begin{tabular}{lccc}
\hline Variabel & Tidak hiponatremia & Hiponatremia & $\mathrm{p}$ \\
\hline Durasi operasi $(\mathrm{jam})$ & $4,67(1,00 \mathrm{~s} / \mathrm{d} 16,00)$ & $3,21(1,00 \mathrm{~s} / \mathrm{d} 15,25)$ & 0,052 \\
Perdarahan intraoperatif $(\mathrm{ml} / \mathrm{kg})$ & $31,29 \pm 38,34$ & $15,41 \pm 13,48$ & 0,024 \\
Balans intraoperatif $(\mathrm{ml} / \mathrm{kg} / \mathrm{jam})$ & $+6,61(-3,76 \mathrm{~s} / \mathrm{d}+46,17)$ & $+4,80(-3,83 \mathrm{~s} / \mathrm{d}+297)$ & 0,243 \\
Diuresis intra operatif $(\mathrm{ml} / \mathrm{kg} / \mathrm{jam})$ & $2,60(0,00 \mathrm{~s} / \mathrm{d} 12,90)$ & $2,32(0,00 \mathrm{~s} / \mathrm{d} 11,38)$ & 0,838 \\
Balans 12 jam pasca-operasi $(\mathrm{ml} / \mathrm{kg} / \mathrm{jam})$ & $+0,65 \pm 1,31$ & $+0,55 \pm 1,07$ & 0,756 \\
Diuresis 12 jam pasca-operasi $(\mathrm{ml} / \mathrm{kg} / \mathrm{jam})$ & $1,75 \pm 1,08$ & $1,58 \pm 0,96$ & 0,514 \\
\hline
\end{tabular}

saat 24 jam pasca-operasi karena 4 orang pindah ke ruang rawat biasa sebelum 24 jam pasca-operasi dan 2 orang dilakukan koreksi menggunakan $\mathrm{NaCl} 3 \%$.

Seluruh subyek yang mengalami hiponatremia memiliki nilai osmolalitas plasma yang normal (285$295 \mathrm{mOsm} / \mathrm{kg}$ ) atau meningkat serta osmolalitas urin di atas $100 \mathrm{mOsm} / \mathrm{kg}$ (Tabel 3). Terdapat 20 (71,43\%) dari 28 subyek yang mengalami hiponatremia pada 12 jam pasca-operasi dan $12(70,59 \%)$ dari 17 subyek yang mengalami hiponatremia pada 24 jam pascaoperasi yang memiliki kadar natrium urin $>30 \mathrm{mEq} / \mathrm{L}$.

Kejadian hiponatremia pada 12 jam pascaoperasi memiliki hubungan bermakna dengan status kegawatdaruratan tindakan operasi yang dilakukan dan jumlah perdarahan intraoperatif (Tabel 4). Duapuluh satu dari total $36(36,84 \%)$ subyek yang menjalani tindakan operasi elektif mengalami hiponatremia, sedangkan pada subyek yang menjalani tindakan operasi cito terdapat 7 dari total $8(87,5 \%)$ subyek yang mengalami hiponatremia. Perbedaan keduanya memiliki nilai p 0,007 .

Sedikit berbeda dengan kejadian hiponatremia pada 12 jam pasca-operasi, pada 24 jam pascaoperasi hanya berhubungan secara bermakna dengan status kegawatdaruratan operasi. Sebelas dari total $46(19,30 \%)$ subyek yang menjalani tindakan operasi elektif mengalami hiponatremia, sedangkan pada subyek yang menjalani tindakan operasi cito terdapat 6 dari total $8(75 \%)$ subyek yang mengalami hiponatremia. Perbedaan keduanya memiliki nilai $\mathrm{p}$ 0,001 .

\section{Pembahasan}

Selama tindakan operasi seluruh subyek mendapat cairan isotonik sebagai cairan parenteral utama, 11 subyek dengan risiko tinggi hipoglikemia, seperti usia di bawah 1 tahun, gizi buruk, atau tindakan operasi melibatkan organ hati, mendapat tambahan cairan dektosa $1 \%$. Cairan isotonik digunakan sebagai cairan utama intraoperatif untuk mencegah terjadinya hiponatremia. Pada kondisi risiko tinggi hipoglikemia dekstrosa diberikan dengan kadar minimal, yaitu 1 atau 2\% karena glukosa yang lebih tinggi dapat menyebabkan terjadinya hiperglikemia dan gangguan elektrolit intraoperatif. ${ }^{19-21}$ Pada penelitian ini hampir seluruh subyek mendapat kristaloid yang mengandung asetat atau campuran asetat dan malat. Cairan kristaloid yang mengandung anion metabolik (asetat, laktat, malat) sebagai prekursor bikarbonat dapat mencegah terjadinya asidosis hiperkloremik, di sisi lain beberapa penelitian menunjukkan adanya peningkatan kadar laktat dalam darah pada populasi yang mendapat cairan dengan buffer laktat. ${ }^{19,21,22}$ 
Pada perawatan pasca-operasi, subyek mendapat cairan hipotonik sebagai cairan rumatan. Kejadian hiponatremia yang tinggi banyak dihubungkan dengan pemberian cairan hipotonik sehingga pemberian cairan isotonik banyak direkomendasikan . ${ }^{1,2,5,8,21}$ Beberapa penelitian lain tidak dapat menunjukkan hubungan antara pemberian cairan hipotonik dengan peningkatan kejadian hiponatremia, bahkan terdapat risiko hipernatremia pada anak yang mendapat cairan isotonik. ${ }^{24-6}$ Keseragaman jenis cairan parenteral yang diberikan menyebabkan analisis mengenai hubungan antara jenis cairan dan kejadian hiponatremia tidak dapat dilakukan.

Secara umum, tidak terdapat perbedaan total cairan yang diberikan selama 12 jam pertama dan 12 jam selanjutnya pasca-operasi. Rerata balans cairan pasca-operasi menunjukkan hasil yang positif dengan total balans positif yang lebih kecil dan jumlah diuresis yang lebih besar saat 24 jam dibandingkan 12 jam pasca-operasi. Perbedaan tersebut bermakna secara statistik tetapi kurang bermakna secara klinis. Peningkatan diuresis yang menyebabkan total balans cairan yang lebih sedikit pada 24 jam pasca-operasi dapat disebabkan oleh dua hal. Pertama, pada jam-jam awal pasca-operasi sangat mungkin terjadi hipovolemia, yang mungkin ringan dan tidak bermanifestasi klinis. Hipovolemia ini dapat disebabkan karena komplikasi tindakan operasi dan hilangnya efek gravitasi akibat berbaring. ${ }^{24,25}$ Kedua, sekresi HAD akan meningkat dalam 6-12 jam pasca-operasi sebagai salah satu respon stres, lalu menurun sesuai kadar sebelum operasi pada hari ketiga sampai kelima. ${ }^{5,11,12,27} \mathrm{Hal}$ tersebut tentunya berpengaruh terhadap kadar natrium plasma, pada 12 dan 24 jam pasca-operasi didapatkan penurunan kadar natrium plasma yang bermakna bila dibandingkan dengan kadar natrium sebelum operasi, dan pada 24 jam pasca-operasi lebih banyak subyek dengan kadar natrium yang berada dalam rentang nilai normal. Hasil ini menarik untuk menjadi pertimbangan dalam menentukan total dan jenis cairan yang diberikan pada 12 dan 24 jam pasca-operasi ke depannya.

Didapatkan kejadian hiponatremia 43,07\% pada 12 jam pasca-operasi dan $26,16 \%$ pada 24 jam pascaoperasi. Hiponatremia terbanyak adalah hiponatremia ringan dan sedang tanpa disertai manifestasi neurologis yang jelas. Kejadian hiponatremia berat hanya 1,54\%. Hasil ini konsisten dengan penelitian lain yang melaporkan prevalens hiponatremia pada anak pasca-operasi berkisar antara 20\%-40\%. ${ }^{6,8,9,16} \mathrm{Au}$ $\mathrm{dkk}^{24}$ melaporkan hasil yang berbeda, yaitu dari 145 pasien anak pasca-operasi hanya $11 \%$ yang mengalami hiponatremia. Hal ini disebabkan kadar natrium plasma yang digunakan sebagai batas hiponatremia lebih rendah, yaitu $130 \mathrm{mEq} / \mathrm{L}$. Salah satu alasan $\mathrm{Au}$ dkk menggunakan batas natrium $130 \mathrm{mEq} / \mathrm{L}$ adalah karena hiponatremia di atas $130 \mathrm{mEq} / \mathrm{L}$ umumnya tidak memiliki makna yang penting secara klinis dan tidak mendapat tata laksana khusus. ${ }^{24}$ Pernyataan ini tidak benar seutuhnya, hiponatremia ringan merupakan hal yang penting karena memberikan kewaspadaan dini terhadap dokter yang menangani sehingga memiliki cukup waktu untuk melakukan tata laksana yang adekuat sebelum timbul penurunan natrium yang lebih jauh dan komplikasi yang berat. ${ }^{6}$ Klinck $\mathrm{dkk}^{28}$ melaporkan bahwa penurunan kadar natrium lebih dari $5 \mathrm{mEq} / \mathrm{L}$ pada pasien pasca-operasi, walaupun kadarnya masih dalam rentang normal, berhubungan dengan peningkatan mortalitas di rumah sakit.

Berbagai penelitian menghubungkan kejadian hiponatremia dengan SHATT. Steele $\mathrm{dkk}^{29}$ melaporkan bahwa pasien pasca-operasi yang mengalami hiponatremia mendapat cairan isotonik berupa salin normal atau ringer laktat, tetapi mengalami natriuresis dan balans cairan pasca-operasi yang positif. Hal ini menunjukkan bahwa kelebihan free water bukan semata-mata dari jenis cairan yang diberikan, tetapi merupakan kombinasi antara berbagai faktor, salah satunya HAD. Evaluasi penyebab hiponatremia yang dilakukan dalam penelitian ini tidak menunjukkan SHATT sebagai penyebab utama. Seluruh pasien yang mengalami hiponatremia memiliki kadar osmolalitas plasma yang normal, atau bahkan meningkat. Total balans cairan positif sebagai faktor yang berhubungan dengan kejadian hiponatremia juga tidak didapatkan dalam penelitian ini. ${ }^{6,12,30}$ Salah satu mekanisme yang berperan dalam menyebabkan terjadinya hiponatremia adalah hiponatremia translokasional, yang terjadi pada kondisi SCS.

Terjadinya SCS pada pasien pasca-operasi dibuktikan melalui penelitian Guglielminotti $\mathrm{dkk}^{18}$ pada pasien pasca artroplasti panggul. Kadar natrium plasma yang menurun tidak berhubungan dengan total balans cairan, tetapi berhubungan dengan nilai OG. Pada kelompok yang mengalami penurunan kadar natrium lebih besar didapatkan nilai OG yang lebih tinggi. Hal ini diyakini karena adanya zat terlarut aktif yang berpindah dari intraselular ke ekstraselular, seperti 
yang terjadi pada SCS. Pemeriksaan osmolalitas plasma menggunakan osmometer sehingga tidak dapat dilihat secara langsung ada tidaknya peningkatan OG.Tidak ada satu pun subyek yang mendapat insulin dan hanya satu subyek yang dilakukan continous renal replacement therapy (CRRT) pasca-operasi. Dengan demikian, nilai osmolalitas plasma yang dihitung diperkirakan akan lebih kecil bila dibanding dengan osmolalitas yang diukur.

Kemungkinan terjadinya SCSdidukung dengan adanya natriuresis dan peningkatan osmolalitas urin. Hal tersebut merupakan efek dari meningkatnya sekresi HAD karena peningkatan osmolalitas plasma dan dehidrasi intrasel akibat hiponatremia translokasional. Walaupun begitu, pada beberapa keadaan tertentu seperti operasi yang melibatkan sistem saraf pusat, dapat juga terjadi cerebral salt wasting. ${ }^{33}$ Penurunan kadar osmolalitas urin pada 24 jam pasca tindakan operasi yang justru diikuti dengan peningkatan kadar natrium urin mendukung adanya zat lain yang memengaruhi osmolalitas urin. Perbedaan etiopatogenesis hiponatremia pada penelitian ini dengan penelitian Eulmesekian dkk dapat menjelaskan perbedaan hasil kejadian hiponatremia pada 12 dan 24 jam pasca-operasi. Pada penelitian ini kejadian hiponatremia 12 jam pasca-operasi lebih banyak bila dibandingkan dengan kejadian hiponatremia 24 jam pasca-operasi, tetapi sebaliknya pada penelitian Eulmesekian. Sick cell syndrome merupakan kondisi yang dikaitkan dengan sakit kritis sehingga kejadian hiponatremia akibat SCS diperkirakan akan lebih banyak terjadi pada jam-jam awal pasca-operasi. ${ }^{18}$ Sedangkan pada SHATT kondisi hiponatremia sangat berhubungan dengan peningkatan sekresi HAD, yang mencapai puncak pada 12 jam setelah operasi dan masih dapat bertahan hingga 3-5 hari., ${ }^{5,11,12,27}$ Penyebab adanya perbedaan etiopatogenesis hiponatremia pada penelitian ini dengan beberapa penelitian lain, yang menunjukkan SHATT sebagai etiologi tersering, belum dapat diketahui.

Kejadian hiponatremia pada 12 dan 24 jam pascaoperasi berhubungan dengan status kegawatdaruratan operasi. Pasien yang menjalani operasi cito lebih banyak yang mengalami hiponatremia dibandingkan dengan pasien yang menjalani operasi elektif. Hal ini mungkin disebabkan karena adanya komorbiditas lain yang memengaruhi kadar natrium plasma pada pasien dengan tindakan operasi cito, mengingat etiopatogenesis hiponatremia sangat banyak dan berhubungan erat dengan penyakit yang mendasari. ${ }^{36,37}$ Penjelasan lainnya adalah karena sick cell syndrome sendiri lebih banyak terjadi pada kondisi sakit kritis yang diikuti dengan gangguan sistem organ. ${ }^{38}$ Penelitian ini memang tidak membandingkan secara langsung mengenai kondisi pre-operatif subyek yang dilakukan tindakan operasi cito atau elektif, tetapi pada prinsipnya tindakan operasi cito berbeda dengan elektif karena adanya kondisi pre-operatif yang lebih berat pada pasien dengan operasi cito, berdasarkan tingginya skor American society of anesthesiology pada pasien dengan tindakan operasi cito. ${ }^{39}$

Kejadian hiponatremia pada 12 jam pascaoperasi juga berhubungan dengan jumlah perdarahan intraoperatif. Hiponatremia terjadi pada subyek yang memiliki perdarahan intraoperatif yang lebih sedikit. Penelitian oleh Klinck $\mathrm{dkk}^{40}$ menunjukkan bahwa perdarahan intraoperatif berhubungan secara bermakna dengan peningkatan kadar natrium pascaoperasi. Adanya kandungan natrium sitrat dalam produk darah, yang berfungsi sebagai anti koagulan, dipikirkan sebagai salah satu penyebabnya. Pemberian transfusi darah akibat perdarahan intraoperatif lebih banyak dilakukan pada saat awal pasca-operasi. Hal ini dapat menjelaskan tidak adanya hubungan antara perdarahan intra-operatif dan kejadian hiponatremia pada 24 jam pasca-operasi. Kemungkinan penyebab lainnya adalah lebih banyaknya jumlah cairan parenteral yang diberikan pada subyek dengan perdarahan intraoperatif. Total balans intraoperatif dan balans 12 jam pasca-operasi tidak berbeda bermakna pada kelompok hiponatremia dan tidak hiponatremia padahal pada kelompok hiponatremia mengalami perdarahan yang lebih sedikit. Hal ini secara tidak langsung menunjukkan bahwa lebih banyak free water yang didapatkan, apalagi cairan utama pasca-operasi yang diberikan adalah cairan hipotonik.

\section{Kesimpulan}

Insidens hiponatremia pada anak pasca tindakan operasi yang dirawat di ruang perawatan intensif anak RSCM selama Mei sampai Desember 2016 adalah $43,07 \%$ dan $26,16 \%$ pada 12 dan 24 jam pasca-operasi. Sindrom hormon antidiuretik tidak tepat (SHATT) tidak terbukti menjadi penyebab utama terjadinya hiponatremia, dan hiponatremia translokasional pada 
sick cell syndrome mungkin berperan dalam terjadinya hiponatremia pada anak pasca tindakan operasi. Hiponatremia yang terjadi pada 12 jam pasca-operasi berhubungan dengan status kegawatdaruratan tindakan operasi dan jumlah perdarahan intraoperatif. Sementara hiponatremia yang terjadi pada 24 jam pasca-operasi hanya berhubungan dengan status kegawatdaruratan tindakan operasi. Sebagai saran, diperlukan penelitian lanjutan dengan jumlah subyek yang lebih banyak dengan menghitung kadar OG untuk melihat secara lebih jelas kemungkinan terjadinya sick cell syndrome dan faktor-faktor yang berhubungan dengan kejadian hiponatremia pada pasien pasca-operasi.

\section{Daftar pustaka}

1. Friedman JN. Risk of acute hyponatremia in hospitalized children and youth receiving maintenance intravenous fluids. Paediatr Child Health 2013;18:102-7.

2. Easley D, Tillman E. Hospital-acquired hyponatremia in pediatric patients: A review of literature. J Pediatr Pharmacol Ther 2013;18:105-11.

3. Moritz ML, Ayus JC. New aspects in the pathogenesis, prevention, and treatment of hyponatremic encephalopathy in children. Pediatr Nephrol. 2010;25:1225-38.

4. Moritz ML, Ayus JC. Hospital acquired hyponatremia - why are hypotonic parenteral fluids still being used? Nat Clin Pract Nephrol 2007;3:374-82.

5. Moritz ML, Ayus JC. Prevention of hospital-acquired hyponatremia: A case for using isotonic saline. Pediatrics 2003;111:227-30.

6. Eulmesekian PG, Perez A, Minces PG, Bohn D. Hospitalacquired hyponatremia in postoperative pediatric patients: Prospective observational study. Pediatr Crit Care Med 2010;11:479-83.

7. Nathan BR. Cerebral correlates of hyponatremia. Neurocrit Care 2007;6:72-8.

8. Choong K, Arora S, Cheng J, Farrokhyar F, Reddy D, Thabane $\mathrm{L}$, dkk. Hypotonic versus isotonic maintenance fluids after surgery for children: a randomized controlled trial. Pediatrics 2011;128:857-66.

9. Septhiandi N, Dewi R, Yanuarso P, Ifran EKB, Amelia N, Hidayati EK. Insiden hiponatremia pasca-operasi mayor pada anak di ruang rawat intensif. Sari Pediatri 2016;17:327-34.

10. Arieff AI. Postoperative hyponatraemic encephalopathy following elective surgery in children. Pediatr Anesth 1998;8:1-4.
11. Lieh-Lai MW, Stanitski DF, Samanik AP, Uy HG, Rossi NF, Simpson PM, dkk. Syndrome of inappropriate antidiuretic hormone secretion in children following spinal fusion. Crit Care Med 1999;27:622-7.

12. Burrows FA, Shutack JG, Crono RK. Inappropriate secretion of antidiuretic hormone in a postsurgical pediatric population. Crit Care Med 1983;11:527-31.

13. Judd BA, Haycock GB, Dalton RN, Chantler C. Antidiuretic hormone following surgery in children. Acra Paediatr Scand 1990;79:461-6.

14. Pillai BP, Unnikrishnan AG, Pavithran PV. Syndrome of inappropriate hormone secretion: revisiting a classical endocrine disorder. Indian J Endocrinol Metb 2011;15:S20815.

15. Way C, Dhamrait R, Wade A, Walker I. Perioperative fluid therapy in children: a survey of current prescribing practices. Br J Anaesth 2006;97:371-9.

16. Puspita R, Pudjiadi A, Pusponegoro H, Perdede SO. Profil pemberian cairan perioperatif serta pengaruhnya terhadap keseimbangan asam basa, elektrolit, dan kadar gula darah. Sari Pediatri 2016;17:335-42.

17. Cerda-Esteve M, Cuadrado-Godia E, Chillaron JJ, PontSunyer C, Cucurella G, Fernandez M, dkk. Cerebral salt wasting: review. Eur J Intern Med 2008;19:249-54.

18. Guglielminotti J, Tao S, Maury E, Fierobe L, Mantz J, Desmonts JM. Hyponatremia after hip arthroplasry may be related to a translocational rather than to a dilutional mechanism. Crit Care Med 2003;31:442-8.

19. Sumpelmann R, Becke K, Crean P, Johr M, Lonnqvist PA, Strauss JM, dkk. European consensus statement for intraoperative fluid therapy in children. Eur J Anaesthesiol 2011;28:637-9.

20. Murat I, Dubois M. Perioperative fluid therapy in pediatrics. Paediatr Anaesth 2008;18:363-70.

21. Busto-Aguirreurreta N, Suarez JJJ. Perioperative fluid therapy in pediatric patient: recommendations. J Perioper Crit Intensive Care Nurs 2016;2:1-5.

22. Cortes DO, Bonor AR, Vincent JL. Isotonic crystalloid solutions: a structural review of the literature. Br J Anaesth 2014;112:968-81.

23. Holliday MA, Segar WE. The maintenance need for water in parenteral fluid therapy. Pediatrics 1957;19:823-32.

24. Au AK, Ray PE, McBryde KD, Newman KD, Weinstein SL, Bell MJ. Incidence of postoperative hyponatremia and complications in critically-ill children treated with hypotonic and normotonic solutions. J Pediatr 2008;152:33-8.

25. Holliday MA, Friedman AL, Segar WE, Chesney R, Finberg L. Acute hospital-induced hyponatremia in cildren: a physiologic approach. J Pediatr. 2004;145:584-7. 
26. Saba TG, Fairbairn J, Houghton F, Laforte D, Foster BJ. A randomized controlled trial of isotonic versus hypotonic maintenance intravenous fluids in hospitalized children. BMC Pediatr 2011;11:1-9.

27. Sterns RH. Disorders of plasma sodium-causes, consequences, and correction. N Eng J Med 2015;372:55-65.

28. Klinck J, McNeill L, Angeantonia ED, Menon DK. Predictors and outcome impact of perioperative serum sodium changes in a high-risk population. Br J Anaesth 2015;114:615-22.

29. Steele A, Gowrishankar M, Abrahamson S, Mazer D, Feldman $\mathrm{RD}$, Halperin ML. Postoperative hyponatremia despite nearisotonic saline infusion: a phenomenon of desalination. Ann Intern Med 1997;126:20-5.

30. Flear CT, Singh CM. Hiponatremia and sick cells. Br J Anaesth. 1973;45:976-94.

31. Gill GV, Osypiw JC, Shearer E, English PJ, Watson ID. Critical illness with hyponatremia and impaired cell membrane integrity - the "sick cell syndrome" revisited. Clin Biochem 2005;38:1045-8.

32. Guglielminotti J, Pernet P, Maury E, Alzieu M, Vaubourdolle M, Guidet B, dkk. Osmolar gap hyponatremia in critically ill patients: evidence for the sick cell syndrome? Crit Care Med 2002;30:1051-5.
33. Guy AJ, Michaels JA, Flear CTG. Changes in the plasma sodium concentration after minor, moderate and major surgery. Br J Surg 1987;74:1027-30.

34. Amini A, Schmidt MH. Syndrome of inappropriate secretion of antidiuretic hormone and hyponatremia after spinal surgery. Neurosurg Focus 2004;16:1-4.

35. Verbalis JG, Goldsmith SR, Greenberg A, Schrier RW, Sterns RH. Hyponatremia treatment guidelines 2007: expert panel recommendations. Am J Med 2007;120:S1-21.

36. Robertson GL, Shelton RL, Athar S. The osmoregulation of vasopressin. Kidney Int 1976;10:25-37

37. Spasovski G, Vanholder R, Allolio B, Annane D, Ball S, Bichet $\mathrm{D}$, dkk. Clinical practice guideline on diagnosis and treatment of hyponatremia. Eur J Endocrinol 2014;170:G1-47.

38. Sharman A, Low A. Vasopressin and its role in critical care. Crit Care Pain 2008;8:134-7.

39. Weissman C, Klein N. The importance of differentiating between elective and emergency postoperative critical care patients. J Crit Care 2008;23:308-16.

40. Klinck J, McNeill L, Angeantonia ED, Menon DK. Predictors and outcome impact of perioperative serum sodium changes in a high-risk population. $\mathrm{Br} \mathrm{J}$ Anaesth 2015;114:615-22. 